\title{
Caligula
}

A Biography

\section{Aloys Winterling}

Translated by Deborab Lucas Schneider,

Glenn W. Most, and Paul Psoinos

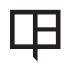

UNIVERSITY OF CALIFORNIA PRESS

Berkeley Los Angeles London 
University of California Press, one of the most distinguished university presses in the United States, enriches lives around the world by advancing scholarship in the humanities, social sciences, and natural sciences. Its activities are supported by the UC Press Foundation and by philanthropic contributions from individuals and institutions. For more information, visit www.ucpress.edu.

University of California Press

Berkeley and Los Angeles, California

University of California Press, Ltd.

London, England

(C) 20 II by The Regents of the University of California

German original (C) Verlag C.H. Beck oHG, München 2003

Library of Congress Cataloging-in-Publication Data

Winterling, Aloys.

[Caligula. English]

Caligula : a biography / Aloys Winterling; translated by Deborah

Lucas Schneider, Glenn W. Most, and Paul Psoinos

p. $\mathrm{cm}$.

Originally published in German: München : C.H. Beck, c2003, with title Caligula : eine Biographie.

Includes bibliographical references and index.

ISBN 978-0-520-24895-3 (cloth, alk. paper)

I. Caligula, Emperor of Rome, I2-4I. 2. Rome-History-Caligula, 37-4I. 3. Emperors-Rome-Biography. I. Title.

$\mathrm{DG}_{2} 83 . \mathrm{W}_{5} 6 \mathrm{I} 3 \quad 20 \mathrm{II}$

$937^{\prime} .07092-\mathrm{dc} 22$

2011012924

Manufactured in the United States of America

$\begin{array}{llllllllll}20 & \text { I9 } & \text { I8 } & \text { I7 } & \text { I6 } & \text { I5 } & \text { I4 } & \text { I3 } & \text { I2 } & \text { II }\end{array}$

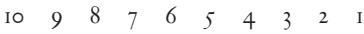

In keeping with its commitment to support environmentally responsible and sustainable printing practices, UC Press has printed this book on Natures Book, which contains $30 \%$ post-consumer waste and meets the minimum requirements of ANSI/NISO Z 39.48-1992 (R 1997) (Permanence of Paper). 


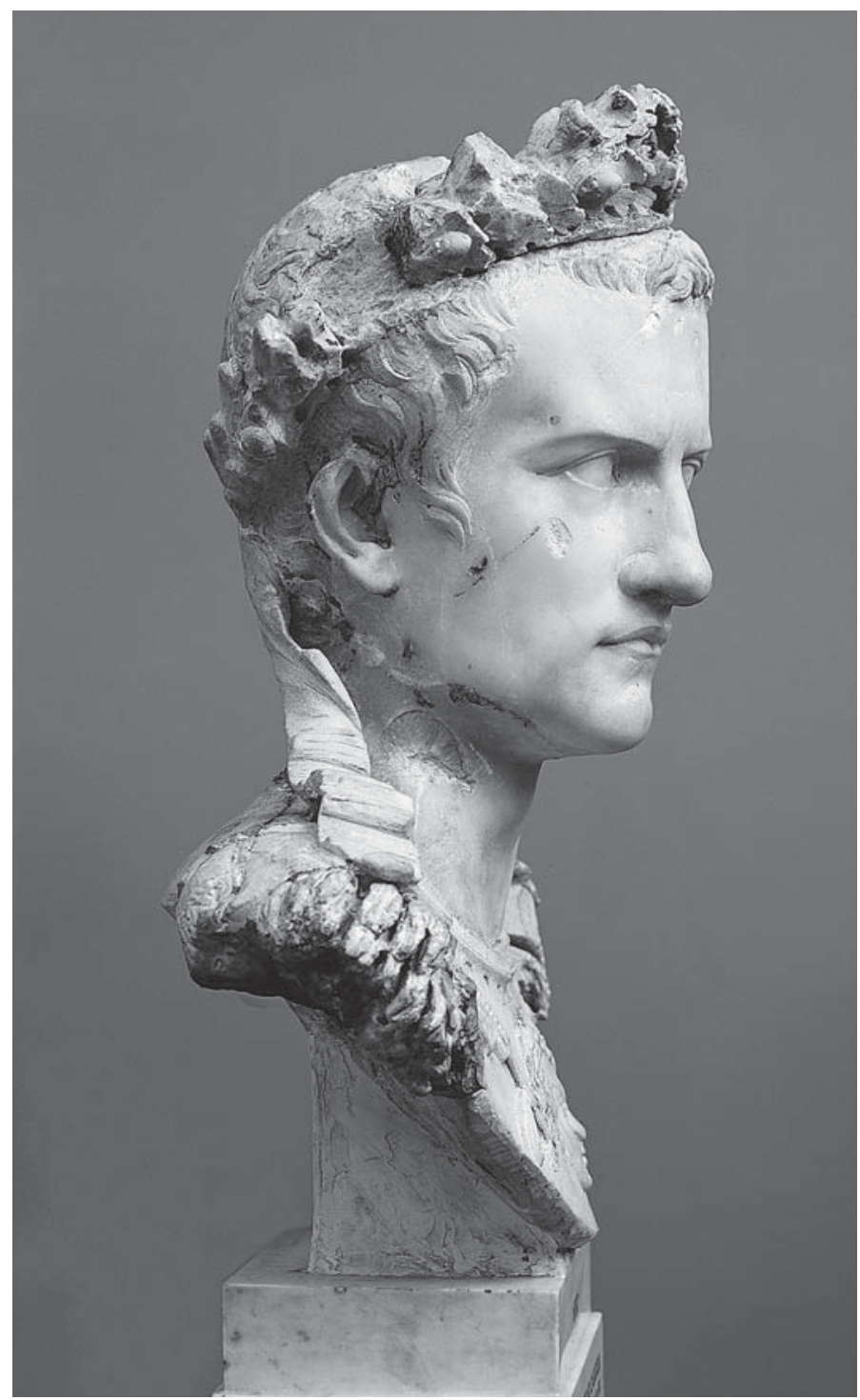

Bust of Caligula. Copenhagen, Ny Carlsberg Glyptotek 637 (Inv. I453). Photo: Ole Haupt. 
Caligula 